\title{
THERMOPHYSICAL PROPERTIES OF MULTICOMPONENT MODEL HIGH-ENTROPY MELTS
}

\author{
M. Dufanets, V. Sklyarchuk (D), Yu. Plevachuk (D) \\ Ivan Franko National University of Lviv, 8, Kyrylo 83 Mefodiy St., Lviv, UA-79005, Ukraine \\ (Received 06 September 2020; in final form 12 November 2020; accepted 24 November 2020;
}

published online 18 December 2020)

\begin{abstract}
Viscosity, electrical conductivity and thermoelectric power of $\mathrm{Cu}-33.3 \mathrm{Bi}-33.3 \mathrm{Sn}, \mathrm{Cu}-25 \mathrm{Bi}-$ $25 \mathrm{Sn}-25 \mathrm{In}, \mathrm{Cu}-20 \mathrm{Bi}-20 \mathrm{Sn}-20 \mathrm{In}-20 \mathrm{~Pb}$ and $\mathrm{Cu}-20 \mathrm{Bi}-20 \mathrm{Sn}-20 \mathrm{Ga}-20 \mathrm{~Pb}$ liquid alloys of equiatomic concentrations, which are components of model multicomponent high-entropy alloys, have been studied experimentally. Based on the obtained results, the activation energy of the viscous flow and the entropy of mixing were calculated. The negative values of the entropy of mixing suggest a structural ordering in the system.
\end{abstract}

Key words: high-entropy alloys, entropy, viscosity, electrical conductivity, thermoelectric power.

DOI: https://doi.org/10.30970/jps.24.4602

\section{INTRODUCTION}

The development of industry requires new construction materials with improved physico-chemical and operational characteristics. Conventional industrial alloys contain several basic elements. As a rule, such alloys are thermodynamically unstable and can undergo a number of phase transformations with increasing temperature, which leads to a deterioration in their performance. Also, such alloys usually form a number of intermetallic compounds, which is the cause of their fragility. Therefore, in recent years, a new class of materials, known as high-entropy alloys (HEA) is being actively studied, which have a high entropy of mixing, which is achieved by a significant number of components ( 5 or more elements) [1]. Such alloys consist of solid solutions (simple crystal structure of bcc, fcc) and have good performance properties. HEAs have high hardness, wear resistance, oxidation resistance, good corrosion and radiation resistance. These characteristics allow us to significantly expand the scope of these alloys.

The peculiarity of such alloys is the dominant formation of disordered solid solutions, stable due to high entropy of mixing. HEAs form a single-phase stable solid substitution solution. Stabilization of the solid solution and prevention of the formation of intermetallic phases during solidification is ensured by the high entropy of mixing in the solid and liquid states.

According to the Boltzmann equation [2], the configurational entropy of a system is:

$$
\Delta S_{\mathrm{conf}}=k_{\mathrm{B}} \ln w,
$$

where $k_{\mathrm{B}}$ is Boltzmann's constant and $w$ is the number of ways in which the available energy can be mixed or shared among the particles in the system. For a random $n$-component solid solution, in which the $i$-th component has a mole fraction $X_{i}$, its ideal configurational entropy per mole is

$$
\Delta S_{\text {conf }}=-R \Sigma_{i}^{n} X_{i} \ln X_{i},
$$

where $R$ is the gas constant, $8.314 \mathrm{~J} / \mathrm{K} / \mathrm{mol}$.
Therefore, the entropy increases as the number of elements increases during the formation of a solid solution. Conversely, intermetallic compounds have an ordered phase, a low configurational entropy, and their entropy is generally zero in the case of a stoichiometric composition [3]. In this work, peculiarities of some structure-sensitive properties in a wide temperature range, namely, temperature dependence of viscosity, electrical conductivity and thermoelectric power of $\mathrm{Cu}-33.3 \mathrm{Bi}-33.3 \mathrm{Sn}, \mathrm{Cu}-25 \mathrm{Bi}-25 \mathrm{Sn}-25 \mathrm{In}, \mathrm{Cu}-$ 20Bi-20Sn-20In-20Pb and $\mathrm{Cu}-20 \mathrm{Bi}-20 \mathrm{Sn}-20 \mathrm{Ga}-20 \mathrm{~Pb}$ liquid alloys of equiatomic concentrations (in at.\%), as components of model multicomponent high-entropy alloys, were studied experimentally.

\section{EXPERIMENTAL DETAILS}

The measurements of the viscosity, $\eta(T)$, were carried out using a computer-controlled oscillating-cup viscosimeter [4]. The dynamic viscosity has been calculated from the corresponding logarithmic decrement of dampi$\mathrm{ng}$ and the period of oscillations by using the Roscoe equation [5]. The experiments were performed in the argon atmosphere under a negligible excess pressure of about 0.02-0.03 MPa. Each sample of about $30 \mathrm{~g}$ was accurately weighed and subsequently placed in a cylindrical graphite crucible with the internal diameter of $14 \mathrm{~mm}$. A homogeneous temperature field up to $0.3 \mathrm{~K}$ in the range of absolute values between the alloy melting temperature and $800 \mathrm{~K}$ was created inside the furnace. The temperature was measured with a WRe$5 / 20$ thermocouple placed just below the crucible. This method of viscosity determination is accurate to within $\pm 5 \%$.

The electrical conductivity, $\sigma(T)$, and the thermoelectric power, $\alpha(T)$, were measured using a contact method in accordance with a four-probe method [6]. The experiments were performed in the argon atmosphere between $800 \mathrm{~K}$ and $1350 \mathrm{~K}$. Graphite electrodes for the current and potential measurements were placed in the wall of a cylindrical BN-ceramic measuring cell along its vertical axis. These potenti- 
al electrodes were equipped with thermocouples for temperature measurements. Single thermoelectrodes of these thermocouples were used for the electrical conductivity and thermoelectric power determination. The melting temperature was measured by WRe-5/20 thermocouples in close contact with the liquid. The cell construction allows to carrying out the electrical conductivity and thermoelectric power measurements simultaneously in one run [7]. In order to obtain reliable data, the measurements were performed several times. The resultant errors of the electrical conductivity and thermoelectric power measurements are about $2 \%$ and $5 \%$, respectively.

\section{RESULTS AND DISCUSSION}

Temperature dependences of the viscosity coefficient for the investigated alloys are presented in Fig. 1. The melts are Newtonian liquids and, similarly to other liquid alloys containing the same elements (see e.g. [8]), the temperature dependence of their viscosity can be described by an Arrhenius-type empirical equation [9]

$$
\eta=\eta_{0} \exp \frac{E_{\mathrm{A}}}{R T}
$$

where $\eta_{0}$ is a constant and $E_{\mathrm{A}}$ is the activation energy of a viscous flow. The results obtained are in agreement with the data reported in [10].

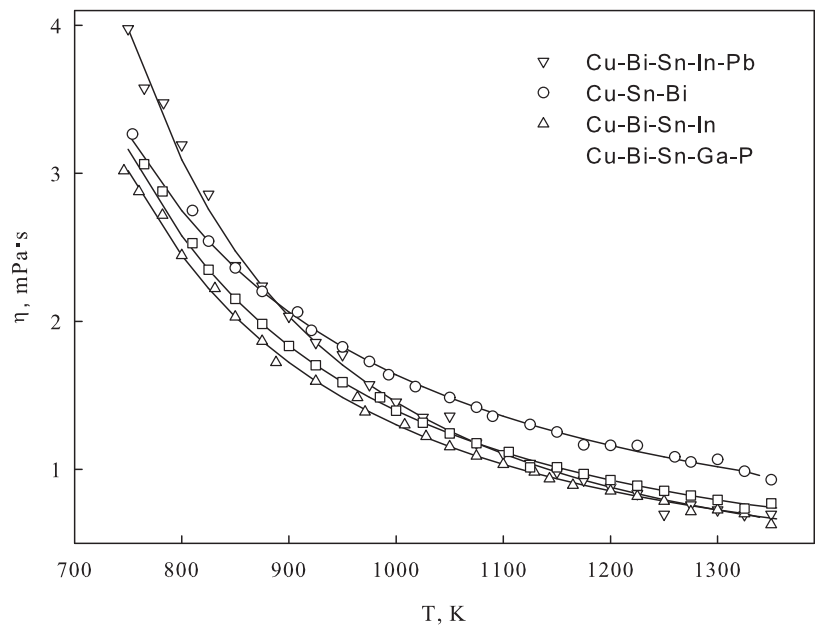

Fig. 1. Viscosity vs. temperature for $\bigcirc: \mathrm{Cu}-33.3 \mathrm{Bi}-33.3 \mathrm{Sn}$, $\triangle:$ Cu-25Bi-25Sn-25In, $\nabla:$ Cu-20Bi-20Sn-20In-20Pb and $\square: \mathrm{Cu}-20 \mathrm{Bi}-20 \mathrm{Sn}-20 \mathrm{Ga}-20 \mathrm{~Pb}$ liquid alloys

The calculated activation energy of a viscous flow, $E_{\mathrm{A}}$, has the following values: $17.2 \mathrm{~kJ} / \mathrm{mol}$ for $\mathrm{Cu}-33.3 \mathrm{Bi}-33.3 \mathrm{Sn}, 21.0 \mathrm{~kJ} / \mathrm{mol}$ for $\mathrm{Cu}-25 \mathrm{Bi}-25 \mathrm{Sn}-$ $25 \mathrm{In}, 25.1 \mathrm{~kJ} / \mathrm{mol}$ for $\mathrm{Cu}-20 \mathrm{Bi}-20 \mathrm{Sn}-20 \mathrm{In}-20 \mathrm{~Pb}$, and $20.4 \mathrm{~kJ} / \mathrm{mol}$ for $\mathrm{Cu}-20 \mathrm{Bi}-20 \mathrm{Sn}-20 \mathrm{Ga}-20 \mathrm{~Pb}$ liquid alloys. From experimental data the parameter $\eta_{0}$ has been determined (see Table 1), allowing us then to calculate the configurational entropy of mixing of the melt $\Delta S$ from the following equation [10]:

$$
\eta_{0}=\frac{\hbar N_{\mathrm{A}}}{\mu} \exp \left(-\frac{\Delta S}{R}\right)
$$

where $\hbar$ is the Plank constant, $N_{\mathrm{A}}$ is Avogadro's number, $\mu$ is the molar mass. The negative entropy values suggest a structural ordering in the melt (Table 1).

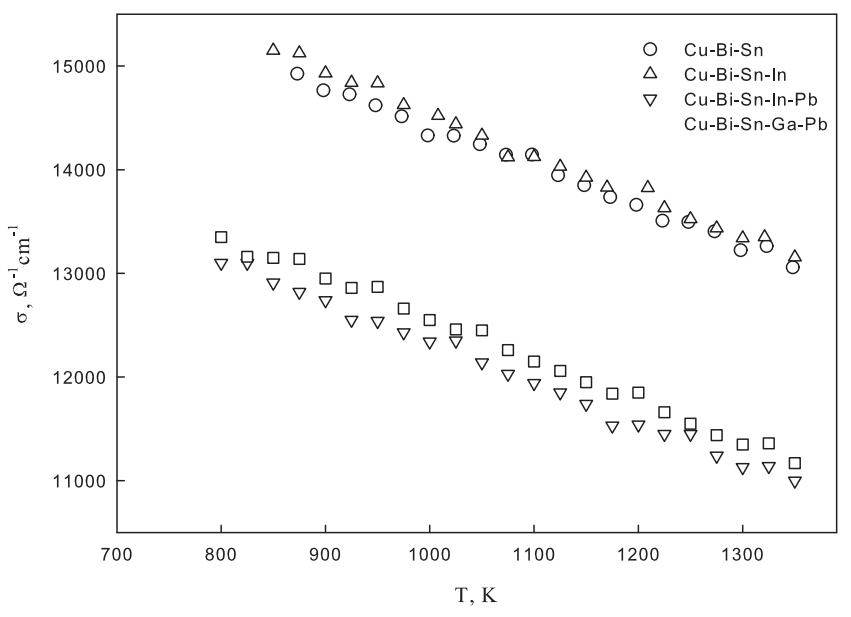

Fig. 2. Electrical conductivity vs. temperature for $\bigcirc: \mathrm{Cu}-$ 33.3Bi-33.3Sn, $\triangle$ : Cu-25Bi-25Sn-25In, $\nabla: \mathrm{Cu}-20 \mathrm{Bi}-20 \mathrm{Sn}-$ $20 \mathrm{In}-20 \mathrm{~Pb}$ and $\square: \mathrm{Cu}-20 \mathrm{Bi}-20 \mathrm{Sn}-20 \mathrm{Ga}-20 \mathrm{~Pb}$ liquid alloys

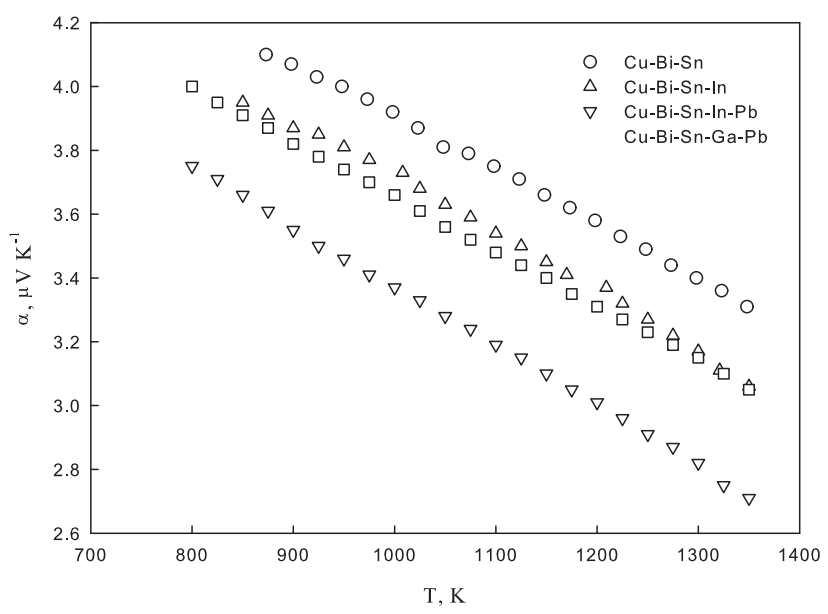

Fig. 3. Thermoelectric power vs. temperature for $\bigcirc: \mathrm{Cu}-$ 33.3Bi-33.3Sn, $\triangle$ : Cu-25Bi-25Sn-25In, $\nabla: \mathrm{Cu}-20 \mathrm{Bi}-20 \mathrm{Sn}-$ $20 \mathrm{In}-20 \mathrm{~Pb}$ and $\square: \mathrm{Cu}-20 \mathrm{Bi}-20 \mathrm{Sn}-20 \mathrm{Ga}-20 \mathrm{~Pb}$ liquid alloys

The results of the experimental temperature dependence of electrical conductivity and thermoelectric power are presented in Figs. 2 and 3. The results obtained for the ternary $\mathrm{Cu}-33.3 \mathrm{Bi}-33.3 \mathrm{Sn}$ system are in good agreement with the data presented in [11], while no literature data for other melts have been found. The electrical conductivity of all investigated alloys decreases linearly in the whole temperature range from $15000 \mathrm{Ohm}^{-1} \cdot \mathrm{cm}^{-1}$ to $13200 \mathrm{Ohm}^{-1} \cdot \mathrm{cm}^{-1}$ for $\mathrm{Cu}-33.3 \mathrm{Bi}-$ 33.3Sn, from $15200 \mathrm{Ohm}^{-1} \cdot \mathrm{cm}^{-1}$ to $13200 \mathrm{Ohm}^{-1} \cdot \mathrm{cm}^{-1}$ for $\mathrm{Cu}-25 \mathrm{Bi}-25 \mathrm{Sn}-25 \mathrm{In}$, from $13000 \mathrm{Ohm}{ }^{-1} \cdot \mathrm{cm}^{-1}$ to 
$11000 \mathrm{Ohm}^{-1} \cdot \mathrm{cm}^{-1}$ for $\mathrm{Cu}-20 \mathrm{Bi}-20 \mathrm{Sn}-20 \mathrm{In}-20 \mathrm{~Pb}$, from $13300 \mathrm{Ohm}^{-1} \cdot \mathrm{cm}^{-1}$ to $11200 \mathrm{Ohm}^{-1} \cdot \mathrm{cm}^{-1}$ for $\mathrm{Cu}-20 \mathrm{Bi}-$ $20 \mathrm{Sn}-20 \mathrm{Ga}-20 \mathrm{~Pb}$ liquid alloys. The absolute electrical conductivity values fully correspond to those typical for metallic melts. It should be noted that the electrical conductivity of five-component alloys containing $\mathrm{Pb}$ is significantly lower.

\begin{tabular}{|c|c|c|c|}
\hline Chemical composition, at. \% & $\eta_{0}, \mathrm{mPa} \cdot \mathrm{s}$ & $E_{\mathrm{A}}, \mathrm{kJ} / \mathrm{mol}$ & $-\Delta S, \mathrm{~kJ} / \mathrm{K}$ \\
\hline $\mathrm{Cu}-33.3 \mathrm{Bi}-33.3 \mathrm{Sn}$ & 0.207 & 17.2 & 22 \\
\hline $\mathrm{Cu}-25 \mathrm{Bi}-25 \mathrm{Sn}-25 \mathrm{In}$ & 0.104 & 21.0 & 20 \\
\hline $\mathrm{Cu}-20 \mathrm{Bi}-20 \mathrm{Sn}-20 \mathrm{In}-20 \mathrm{~Pb}$ & 0.071 & 25.1 & 18.5 \\
\hline $\mathrm{Cu}-20 \mathrm{Bi}-20 \mathrm{Sn}-20 \mathrm{Ga}-20 \mathrm{~Pb}$ & 0.120 & 20.4 & 15 \\
\hline
\end{tabular}

Table 1. Parameters of approximation of equations (3), (4)

Thermoelectric power of all the alloys studied has positive values and decreases as temperature increases, namely, from $4.1 \mu / \mathrm{K}$ to $3.3 \mu / \mathrm{K}$ for $\mathrm{Cu}-33.3 \mathrm{Bi}-33.3 \mathrm{Sn}$, from $3.9 \mu / \mathrm{K}$ to $3.1 \mu / \mathrm{K}$ for $\mathrm{Cu}-25 \mathrm{Bi}-25 \mathrm{Sn}-25 \mathrm{In}$, from $3.8 \mu / \mathrm{K}$ to $2.7 \mu / \mathrm{K}$ for $\mathrm{Cu}-20 \mathrm{Bi}-20 \mathrm{Sn}-20 \mathrm{In}-20 \mathrm{~Pb}$, and from $4.0 \mu / \mathrm{K}$ to $3.0 \mu / \mathrm{K}$ for $\mathrm{Cu}-20 \mathrm{Bi}-20 \mathrm{Sn}-20 \mathrm{Ga}-20 \mathrm{~Pb}$ (see Fig. 3).

It is obvious that all the variety of structural transformations in condensed matter physics are concentrated in the processes of melting and solidification. Formation (or disappearance) of a long-range order, the nature of short-range ordering also change both in terms of integral characteristics (coordination of atoms, average interatomic distance) and in terms of the nature of individual motion of atoms. Particularly big structural changes occur in alloys containing semi-metals. These changes are manifested in the anomalous behavior of electrical conductivity, as well as in the fact that the thermoelectric power acquires values close to the values predicted by the of nearly-free electron theory. It is clear that such a significant change in the state of the system must be reflected in such a fundamental characteristic as the entropy of the process $\Delta S$.

According to Mott's model [12], entropy can be roughly defined as

$$
\Delta S_{1}=\frac{1}{80} \ln \frac{\sigma_{\mathrm{s}}}{\sigma_{\mathrm{l}}},
$$

where $\sigma_{\mathrm{s}}$ and $\sigma_{\mathrm{l}}$ are electrical conductivities in the solid and liquid states. However, as it turned out later, this formula has restrictions. It is well known that in almost all cases the electrical conductivity of metals decreases when they melt. The increase in conductive must be connected with melting entropy. A number of authors sought to separate the entropy of both liquids and solids into parts connected with different physical mechanisms [13], and if this is applied to melting, we have

$$
\Delta S=\Delta S_{\mathrm{v}}+\Delta S_{\mathrm{el}}+\Delta S_{\mathrm{s}} .
$$

Here $\Delta S$ is the entropy of melting, $\Delta S_{\mathrm{v}}$ and $\Delta S_{\mathrm{s}}$ the vibrational and structural contributions, respectively. The first component $\Delta S_{\mathrm{v}}$ takes into account the disappearance of the long-range order and, in accordance with the theory of structural diffusion, contains information about the change in the spectrum of atoms oscillations near the centers of equilibrium. Therefore, we can assume that $\Delta S_{\mathrm{v}}=\Delta S_{1}$ from Eq. (1). The second component $\Delta S_{\mathrm{el}}$ is the change in the entropy of the charge carrier transfer and in accordance with the thermodynamics of irreversible processes $\Delta S_{\mathrm{el}}=F \Delta \alpha$, where $F$ is the Faraday constant and $\Delta \alpha$ is a change of thermoelectric power during melting.

The third component $\Delta S_{\mathrm{s}}$ describes the change in the structure of the short-range order during melting, including atomic dynamics, taking into account cooperative processes. Since there is no correct expression for $\Delta S_{\mathrm{s}}$, we assume empirically that it is proportional to the relative change in the coordination number $Z$.

Thus, the entropy of melting can be expressed as [13]:

$$
\Delta S=\frac{1}{80} \ln \frac{\sigma_{\mathrm{s}}}{\sigma_{\mathrm{l}}}+F \Delta \alpha+\Delta S\left(\frac{Z_{\mathrm{l}}-Z_{\mathrm{s}}}{Z_{\mathrm{s}}}\right) .
$$

The values of the melting entropy calculated by this formula for a number of metals that are parts of the investigated melts show that more than a half of the $\Delta S$ consists of electronic and structural contributions. This confirms the complex entropy structure of the "meltingsolidification" process, connected with a rearrangement of the interparticle interaction types.

\section{CONCLUSIONS}

The structure sensitive properties (viscosity, electrical conductivity and thermoelectric power) of multielement liquid alloys of equiatomic compositions, which are components of model multicomponent high-entropy alloys, have been studied experimentally. Based on the obtained results, the activation energy of the viscous flow and the entropy of mixing were calculated. Negative values of entropy obtained from the experimental viscosity data indicate structural ordering in the melt. It is shown that the complex structure of entropy of the melting-solidification process is due to the rearrangement of the nature of the interparticle interaction which leads to the melt ordering.

This study was supported by The Ministry of Education and Science of Ukraine (number of state registration of the Project: 0119U002204). 
[1] M. C. Gao, J.-W. Yeh, P. K. Liaw, Y. Zhang, HighEntropy Alloys. Fundamentals and Applications (Springer International Publishing Switzerland, 2016); http s://doi.org/10.1007/978-3-319-27013-5.

[2] D. R. Gaskell, D. E. Laughlin Introduction to the Thermodynamics of Materials, 6th ed. (CRC Press, Taylor and Francis Group, Boca Raton, 2017); https: //doi.org/10.1007/s10853-018-2265-9.

[3] D. B. Miracle, O. N. Senkov, Acta Mater. 122, 448 (2017); https://doi.org/10.1016/j.actamat.20 16.08 .081$.

[4] S. Mudry, V. Sklyarchuk, A. Yakymovych, J. Phys. Stud. 12, 1601 (2008); https://doi.org/10.30970/jps.12. 1601.

[5] S. Mudry, Yu. Plevachuk, V. Sklyarchuk, A. Yakymovych, J. Non-Cryst. Solids 354, 4415, (2008); https: //doi.org/10.1016/j.jnoncrysol.2008.06.061.

[6] Y. Plevachuk, V. Sklyarchuk, Meas. Sci. Technol. 12, 23 (2001); https://doi.org/10.1088/0957-0233/12/1
$/ 303$.

[7] L. Bulavin et al., J. Nucl. Mater. 433, 329 (2013); https: //doi.org/10.1016/j . jnucmat. 2012.08.045.

[8] A. Dobosz, Yu. Plevachuk, V. Sklyarchuk, B. Sokoliuk, T. Gancarz, Fluid Phase Equilib. 465, 1 (2018); https: //doi.org/10.1016/j.fluid.2018.03.001.

[9] H. Eyring, M. S. John, Significant Liquid Structure (Wiley, New-York, USA, 1969).

[10] O. A. Chikova, V. S. Tsepelev, V. V. V'yukhin, Russ. J. Non-Ferr. Met. 56, 246 (2015); https://doi.org/10.3 103/S1067821215030037.

[11] C. Li, S. Du, D. Zhao, G. Zhou, H. Geng, Phys. Chem. Liq. 52, 122 (2014); https://doi.org/10.1080/003191 04.2013 .806214$.

[12] M. Jonson, G. D. Mahan, Phys. Rev. B 21, 4223 (1980); https://doi.org/10.1103/PhysRevB.21.4223.

[13] N. Cusack, J. E. Enderby, Proc. Phys. Soc. 75, 395 (1960); https://doi.org/10.1088/0370-1328/75 /3/310.

\title{
ТЕПЛОФІЗИЧНІ ВЛАСТИВОСТІ БАГАТОКОМПОНЕНТНИХ МОДЕЛЬНИХ ВИСОКОЕНТРОПІЙНИХ РОЗПЛАВІВ
}

\author{
М. Дуфанець, В. Склярчук, Ю. Плевачук \\ Лъвівсъкий національний університет імені Івана Франка, \\ вул. Кирила і Мефоділ 8, Лъвів, 79005, Украӥна
}

Більшість промислових сплавів є здебільшого термодинамічно нестабільними і, за зростання температури, у них можуть відбуватися фазові переходи, що призводить до погіршення експлуатаційних характеристик. У таких сплавах зазвичай утворюється низка інтерметалевих сполук, що є причиною крихкості. Високоентропійні сплави мають високу ентропію змішування, що досягається кількістю складників від 5 і більше елементів, концентрація яких може змінюватися від 5 до 35 ат.\%. Такі сплави складаються з твердих розчинів (проста кристалічна структура ОЦК, ГЦК) і мають добрі експлуатаційні характеристики. Стабілізація невпорядкованих твердих розчинів забезпечується високою ентропією змішування. Стабілізація однофазового твердого розчину й запобігання утворенню інтерметалевих фаз у процесі кристалізації - високою ентропією змішування в початковому рідкому стані. Ентропія під час утворення твердого розчину збільшується зі зростанням кількості елементів відповідно до гіпотези Больцмана. I навпаки, інтерметалеві сполуки мають упорядковану фазу й низьку конфігураційну ентропію, а за стехіометричного складу їхня ентропія взагалі дорівнює нулеві. Ці сплави характеризуються сповільненими значеннями дифузії та ефектом перемішування, високими твердістю і зносостійкістю, стійкістю до окислення, а також високими корозійною й радіаційною стійкістю, що дозволяє значно розширити сферу їх застосування.

У роботі експериментально досліджено в'язкість (методом згасальних крутильних коливань циліндра, заповненого рідиною), електропровідність та термоЕРС (контактним методом, за 4-точковою схемою) розплавів $\mathrm{Cu}-\mathrm{Bi}-\mathrm{Sn}, \mathrm{Cu}-\mathrm{Bi}-\mathrm{Sn}-\mathrm{In}, \mathrm{Cu}-\mathrm{Bi}-\mathrm{Sn}-\mathrm{In}-\mathrm{Pb}, \mathrm{Cu}-\mathrm{Bi}-\mathrm{Sn}-\mathrm{Ga}-\mathrm{Pb}$ в еквіатомних концентраціях, які є компонентами модельних високоентропійних розплавів. На основі отриманих результатів розраховано енергію активації в'язкої течії й ентропію змішування. Значення ентропії плавлення, розраховані для низки металів, що входять до складу досліджених розплавів, свідчать про те, що внесок електронного та структурного компонентів переважає. Це підтверджує складну ентропійну структуру процесу “плавлення-кристалізація”, пов'язану з перебудовою типів міжчастинкових взаємодій.

Ключові слова: зонна енергетична структура, парціальна густина станів, загальна густина станів, сцинтилятори, лантаніди. 